\title{
Foreign Direct Investment and the Development of the Casablanca Stock Exchange
}

\author{
JihaneAayale \\ Wuhan University of Technology, Wuhan, Hubei, China
}

2690145975@qq.com / aayalejihane26@gmail.com

\begin{abstract}
This paper aims to empirically examine the impact of Foreign direct investment in developing host countries' stock markets development, in our case Morocco's Casablanca stock exchange, while investigating the effect of domestic savings and exchange rate among other variables, we utilized market capitalization as a proportion of GDP, Mad-Dollar exchange rate and Net FDI inflow as proxies for our analysis, using a multiple regression analysis (OLS) with annual time series data for the selected time period of (1993-2013). We estimated an empirical relationship between these variables and tried to depict a closer relationship between Foreign Direct Investment and Stock Market Development, we hypothesized that the increased Foreign Direct Investment in Morocco has a positive effect on its stock market development. The results show a negative impact of foreign direct investment on stock market development, along with a positive impact of the other explanatory variables on the development of the Casablanca Stock Exchange.
\end{abstract}

Key Words. Foreign direct investment, Stock market development, Exchange rate, OLS, Market capitalisation, Gross domesticsavings.

\section{Introduction}

To augment their share of FDI flows, developing countries smoothen constraints on foreign direct investment, as well as fortify their macroeconomic stability, escalate the privatisation of stateowned companies, commence domestic financial reforms and the liberation of capital accounts, implement enticing tax incentives and subsidies...

One of the main responsibilities of sstock markets isdirecting funds in the direction of investment projects, thus, thereis a positive relationshipbetween FDI and financialmarkets; Stock markets in particular, enactstructural changes in pursuance of foreigninvestment. Despitethis, the amplitude of the FDI's impact on emerging stock market development located in developing countries has received very little attention.

Most of the studies focusing on the relationship between FDI and financial market development place economic growth at the core of this liaison; and when analyzing this association results may rely on whether the variables examined are pertinent to stock markets and banking, the ulterior can sometimes be inconclusive and vague. Similarly, a two-way relationship between stock markets development and FDI can be noticed in an emerging economy; FDI through its investment spillover effects contribute to the development of local stock markets, it raises the probability of multinational companies listing their activities in these stock markets and encourages the institution and adoption of investor friendly regulations; analogously, a well-functioning stock market attracts FDI inflow.

In this paper, we perform an empirical assessment of the association between financial market development and FDI using data from the emerging market of Morocco, the advantage of choosing an emerging market is that data is available for this particular country, and explanatory variables linking economic development and other indicators won't have a considerable impact on the results. 


\subsection{Institutional Background}

Following political and financial changes in developing countries, foreign Direct Investment (FDI) has quickly matured, and despite the fact that consistent flow of capital have been very difficult to attract in the North Africanregion, especially following recent political events, the Moroc can government tried it's best to increase the inflow of foreign capital; to do just that, a series of facilitating reforms, macro economic policies, national privatisation programs and trade liberalisation have been encouraged.

Indeed, Morocco proposes conditions that are favorable to investors, such as the strategic position of the kingdom (Morocco's economic development plan relies a great deal on using its location as leverage, it is positioned along the Strait of Gibraltar bounded by Spain and Africa, the kingdom is trying to capitalize on its adjacency to Europe to make the country a regional manufacturing and export hub for international companies), the low salaries and a young population not to mention the accommodating legal framework and assistance; that being said, Morocco's domestic market still has its limitations, the economy still depends on agriculture and the fluctuation in the prices of hydrocarbons, further, bureaucracy has a weighing impact on decision making processes.

\subsection{Casablanca stock exchange}

The Casablanca Stock Exchange was established in 1929, it has also undergone since then many transformations, the most important one was in 1993 giving birth to the stock market that we seetoday, a private company with the status of a limited company, Bourse de Casablanca SA, the capital is equitably held by the brokerage houses; it accomplishes one of the best performances in the MENA region being Africa's largest stock market after Johannesburg Stock Exchange and the Nigerian Stock Exchange in Lagos.

\section{Literaturereview}

Evidently, a well-managed well-functioning stock market draws foreign investments to a country, most studies show a positive relationship between FDI and Stock market development; Studies like Claessens, Klingebiel, \& Schmukler (2001), Adam and Tweneboah (2009), found a strong positive relationship between foreign direct investment and stock market development, Reruns (1983) observed that foreign capital inflows have an effect on stock market development and positively impacts investor participation. Nazir, Nawaz \& Gilani (2010) work shows significant positive relationship between FDI and growth of economy. Torre, Gozzi \& Schmukler (2006) argues that the reforms in a country via privatisation and supervisory improvements results in the development of its Stock markets. Kalim \& Shahbaz (2009), Baker, Foley \& Wurgler (2004), Halalmeh \& Sayah (2010) also found a positive consequence of FDI on stock market development, Garcia and Liu (1999), Demirguc-Kunt and Levine (1996), Yartey and Adjasi (2007) analyzed the link between macroeconomic variables, financial reform financial market development, financial reform and other factors; Singh (1997) finds a positive relationship between economic growth and stock market development.

Further, there have been a good amount of research on determinants of financial sector development recently, and a respectable number of empirical studies on the role of FDI; this research suggests that FDI in host countries is a substantial source of capital along with domestic private investment, leading to the creation of job opportunities and to the improvement of technology transfer strengthening the economic growth process, Yartey (2008) for instance argues that foreign investment is linked to regulatory reform, transparency and ethical trading practices which inspires the investor's confidence, leading to more capital inflows and investments.

Other studies have shown that financial development raises savings rates and increases economic growth (Naceur, Ghazouani, \& Omran 2007), whilstKalim \& Shahbaz (2009) statistically proved a significant positive association between Stock market development and the rate of savings; there fore there'sa causal relationship between FDI, economic growth and stock market development.

Whatis more, the macroeconomic stability of the country is a critical determinant for the development of a stock market, a stable economy attracts foreign investors; in order to measure the 
macroeconomic stability of a country, werefer to a few studies that found a relationship between exchange rate and Stock market using unit root and integration tests (Tabak 2006), Dimitrova's (2005) resultson the other hand, reported that depressing stock markets may emanate from depreciating currency and vice versa, however, other researchers affirmed that stock market development is only possible if the fluctuations in the exchange rateis stable (Subair \& Salihu 2010), or observed a mixed relationshipbetweenexchange rate and stock prices (Parsva\&Lean 2011).

This paper, hopes to fill the gap in the literature about the moroc can stock market particularly because of the lack of empirical studies about the kingdom, and especially in the light of recent political and economical changes in light of the tensions the north African region has been subject to (notably the Arabspring manifestations in neighbouring countries) which has significantly impacted the foreign investment inflows.

Our paper is organis as follows, justlike the first section provided a brief introduction and literature review, the second one willtry to outline the kingdom's foreign investment climate and strategies and a brief history of the casablanca stock exchange, moving on to section 3 to discuss the Methodology and the model with data collection methods; the final section will expose our empirical finding along with the conclusion to our study.

\section{Methodology and data collection}

As the aim of this paper is to examine the impact of foreign direct investment on stock market development in Moroccousing multiple regressionsanalysis, we make use of market capitalsaction as a proportion of GDP, Mad-Dollar exchange rate and Net FDI inflow are the variables we have chosen to investigate this impact.

The Data gathered is in the following time frame (1993-2013), the purpose of choosing the year 1993 as a starting point to our analysisis justified by the fact that the Casablanca stock exchange under went some very important structural changes atthat time, and the logic behind the inclusion of the variables and their sources is discussed below:

\subsection{Stock Market Development}

We shall measure stock market development using market capitalsaction as a proportion of GDP, which is equal to the total market value of listed shares divided by GDP, the reason for this measure is that it is not as arbitrary as other measures of stock market development (Demirguc-Kunt and Levine, 1996).

The annual data was obtained from IMF- World Bank World Economic Indicators and World Bank.

\subsection{The Nominal Exchange Rate}

Currency-risk is para mount to foreigninvestors, indeed, macroeconomic stability plays an important role in attracting FDI and in the development of the stock market, so we use MAD-USD exchange rate as a measure of macroeconomic stability. (Data was obtained from Penn World Table).

\subsection{Net Foreign Direct Investment (FDI) Inflow}

In this study we use the difference between outward and inward FDI in million USD, the net value represents a country's share of FDI inflow.

\subsection{Domestic Savings}

Gross domestic savings (current USD) is used as a proxy for Domestic Savings and we also expect a positive significant impact of Domestic Savings on Stock market development according to the literature.

\section{Empirical Results and Discussion}

\subsection{OLS Analysis}

Having established that the variables's level of integration using the ADF test, we proceed to test for Multiplere gressions. Since our sample size (time series) is less than a few hundred observations, we established that some simple regression tool or just a charting of our data is 
enough to make a certain point, and since the main objective of this study is to identify and analystse the role of Foreign Direct Investment in Developing Stock Markets, our Hypothesis is:

The increased Foreign Direct Investment in Morocco has a positive effect on stock market development.

We use the following model in the form of an equation to investigate the impact of Foreign Direct investment on Stock Market Development along with the exchange rate:

$$
\text { Eq. } 1 \mathrm{LnMC}=\beta 0+\beta 1 \ln \mathrm{FDIN}+\beta 2 \ln \mathrm{ER}+\beta 3 \ln \mathrm{GDS}+\mathrm{U}
$$

Where: $\mathrm{MC}=$ Market capitalisation, proxy for Stock Market Development

FDIN= Foreign Direct Investment, net inflows

$\mathrm{ER}=$ Exchange Rate

GDS $=$ Gross domesticsavings, current USD

(In the above equation, natural log values of the variables are used to transform it into a linear equation and to facilitate the use of ordinary least square method).

\subsection{Results}

An ordinary least square (OLS) regression method was applied to determine the impact of Foreign Direct Investment on Stock Market Development in Morocco. The regression results for the model are reported in the following table.

Fig.1 Multiple regression equation output (Source: computed by author using the views software)

$\begin{array}{lllll}\text { Variable } & \text { Coefficient } & \text { Std. Error } & \text { t-Statistic } & \text { Prob } \\ \text { C } & -2,047438 & 1,994147 & -1,026724 & 0,3208 \\ \text { LNGDS } & 1,712397 & 0,204392 & 8,378020 & 0,0000 \\ \text { LNER } & 0,544863 & 0,793103 & 0.687002 & 0,5026 \\ \text { LNFDIN } & -0,115137 & 0,056789 & -2,027444 & 0,0608 \\ \text { R-squared } & 0,883831 & \text { Mean independantvar } & 3,541999 \\ \text { Adjusted } & \text { R- } & 0,860478 & \text { S.D. Devpendentvar } & 0,715128 \\ \text { squared } & 0,267119 & \text { Akaike info criterion } & 0,382422 \\ \text { S.E. of regression } & 1,070292 & \text { Schwarz criterion } & 0,581252 \\ \text { Sum squared reside } & 0,366988 & \text { Hannan-Quinn Criter. } & 0,416072 \\ \text { Log likelihood } & 38,00385 & \text { Durbin-Watson stat } & 0,930626\end{array}$

F-statistic $\quad 0,000000$

Prob(F-statistic)

The results above indicate that GDS statistically significant at 5\%, where FDIN is signific an that $10 \%$ and ER shows insignificant results.

The adjusted R- squared value is 0.860478 , implying that $86 \%$ of the variation in the stock market development (proxiedhere by market capitalisation) is explained by the independent variables, Foreign direct investment, gross dome sticsavings and exchange rate, which is an indication of a very good fit.

The Durbin-Watson statistic is 0,930626 which not very close to 2 but some how still suggests that there is no major auto correlation problem which implies that the regression has economic meaning. The overall equation is statistically significant as shown by the probability value of the Fstatistic (0.000000).

\subsection{Diagnostic tests}

In order to examine the robustness of the model used diagnostic tests were also conducted; the results are as follows:

-Breach-Godfrey Serial Correlation LM Test: Nullhypothesisis No seriallycorrelatederrors, the results are F-statistic $=1,61 /$ Prob. Chi-Square $=0,15$, wethenfail to reject $\mathrm{H} 0$. 
-Normality Test: Nullhypo thesisis errors are normally distributed, the results are Jarque-Bera= 2,23/ Probability $=0,32$, wethenfail to reject $\mathrm{H} 0$.

-Heteroskedasticity Test (Breusch-Pagan-Godfrey): Nullhypoth esisis Homosc edasticity, the results are F-Statistic $=1,30$ / Prob. Chi-Square $=0,41$ sowecan'treject H0.

The diagnostic test suggests a good fit of the model. The model does not suffer from the problems of non-normality of the errors, serially correlated errors and heteroskedasticity which can be seen from all the probability values which are greater than $5 \%$.

\section{Conclusions}

The analysisin this paperaims to investigate which macroeconomic variables, granted with a special interest in FDI, affect stock market development of Moroc cospecifically. Twenty years of data was collected (1993-2013), and the multiple Regression analysis conducted gave us the following result, the model explains 86 percent of the variation in the dependent variable and the co-efficient sign for the direct foreign investment (FDIN) is negative, rejectingour expected hypothesis; which implies that an increase in FDI will result in adecrease of 0,11 in Stock market Development and that the Foreign direct investment has a negative impact over Stock Market Development, contradicting the literature along with previou sempirical studies conducted in other countries, which can either beex plained by an insufficiency in the data observed or by a collinearity between some variables.

Domestic Savings (GDS) on the other hand has a positive effect on our dependent variable, indeed an increase in Domestic savings causes the Stock Market Development to increases by 1.71, this result is in accordance to previous theories.

The Exchange rate result shows that an increase in the exchange rate means there will be a positive impact over the stock market by 0,54 , which also contrary to the literature as Dimitrova (2005) found that, the depreciation in currency of a country will result in depressing the Stock Market of that country.

The purpose of this study is to analyzese the role of FDI along with other important variables in the stock market development of a developing country like Moroc cosince very country has its own local dynamics. The result of thisstudy and its implication must be further explored and explained by the author and future researchers.

\section{References}

[1] Agarwal, S. (2001). Stock Market Development and Economic Growth: Preliminary Evidence from African Countries. Journal of Sustainable Development in Africa, 3(1), 48-56.

[2] Alfaro, L. (2003). Foreign Direct Investment and Growth: Does the Sector Matter? Harvard Business School.

[3] Demirguc-Kunt, A. and R. Levine, 1996. 'Stock Market Development and Financial Intermediaries:Stylized Facts', World Bank Economic Review, 10(2): 291-321.

[4] Dimitrova, D. (2005). The Relationship between Exchange Rates and Stock Prices: Studied in a Multivariate Model. Issues in political Economy, 14, 1-25.

[5] Garcia, F. V. \& Liu, L. (1999). Macroeconomic Determinants of Stock Market Development.Journal of Applied Economics, 2(1), 29-59.

[6] Naceur, B. S., Ghazouani, S. \&Omran, M. (2007). The determinants of stock market development in the Middle-Eastern and North African region.Emerald Managerial Finance, 33(7), 477-499. DOI 10.1108/03074350710753753.

[7] Singh, A. (1997) Financial Liberalization, Stock Markets, and Economic Development. The Economic Journal, 107(442), 771-782.

[8] Subair, K. \&Salihu, M. O. (2010). Exchange Rate Volatility and the Stock Market: The Nigerian Experience. 
[9] Yartey, C. A. and C. K. Adjasi, 2007. "Stock Market Development in Sub-Saharan Africa: Critical Issues and Challenges" IMF Working Paper 07/209. Washington DC: International Monetary Fund. 